\title{
石炭燃焼ボイラ火炉管用 $\mathrm{Cr}_{3} \mathrm{C}_{2}-\mathrm{NiCr}$ 溶射皮膜の 実験室的評価*
}

\author{
京 将司 $^{* *}$, 中森正治***, 石橋 修 $^{\dagger}$, 黒川一哉 ${ }^{\dagger}$ \\ ** 関西電力株式会社 電力技術研究所 \\ ****株式会社高温腐食防食テクノサーチ \\ $†$ 大阪富士工業株式会社 技術センター \\ †† 北海道大学大学院工学研究院 \\ 附属エネルギー・マテリアル融合領域研究センター
}

\section{Laboratory Evaluation of $\mathrm{Cr}_{3} \mathrm{C}_{2}-\mathrm{NiCr}$ Spray Coatings for Water Wall tubes of Coal Firing Boiler.}

\author{
Shoji Kyo ${ }^{* *}$, Masaharu Nakamori*** ${ }^{*}$ Osamu Ishibashi ${ }^{\dagger}$ and Kazuya Kurokawa ${ }^{\dagger \dagger}$ \\ ** Power Engineering Research and Development center, Kansai Electric Power Co.,INC. \\ *** High Temperature Corrosion \& Protection Technoserch \\ Technical center, Osakafuii Co.Ltd. \\ $\dagger^{\dagger}$ Center for Advanced Research of Energy and Materials, \\ Faculty of Engineering, Hokkaido University
}

\begin{abstract}
Long-term stability operation is requested in the boiler for thermal power generation. Recently, thinning in the tube of heat exchanger due to the grooving corrosion has been actualized in the pulverized coal combustion boiler. Corrosion damage with the grooving corrosion was detected in the burner zone and nearby area with high thermal load as a consequence of cyclic thermal stress (localized tube surface temperature fluctuation on account of slag detachment and tube surface temperature fluctuation induced by wall blower operation and other causes) on the furnace side of the tube wall in an atmosphere containing $\mathrm{H}_{2}, \mathrm{H}_{2} \mathrm{~S}$, and $\mathrm{O}_{2}$, which leads to cracking of the corrosion product layer. Thermal spray coatings applied to the surface of boiler components such as heat exchanger tubes are effective as the countermeasure. In this paper, the $\mathrm{Cr}_{3} \mathrm{C}_{2}-\mathrm{NiCr}$ spray coating was performed by the high-velocity oxygen fuel spraying (HVOF) and the atmospheric plasma spraying (APS). The characteristics of the spray coatings were evaluated by adhesive strength, high temperature hardness, and the abrasive wheel wear test, the high temperature erosion test, and the high temperature corrosion test, etc. The evaluation results proposed the method of evaluating the spray coatings to apply to the coal fired boiler in the laboratory.
\end{abstract}

Key words : high temperature corrosion, pulverized coal firing boiler, water wall tube, wall blower, grooving corrosion, sulfidation, erosion, thermal spray coating, atmospheric plasma spraying, high velocity oxygen fuel spraying

\section{1. 緒}

\section{言}

大容量の微粉炭燃焼ボイラは, 主軸電源として長期安 定運転が求められている。しかし, 燃焼灰由来のボイラ 伝熱管の損傷が多発し, 長期安定運転に支障を来してい る.

その損傷は，燃焼灰が伝熱面に付着・堆積するために 伝熱阻害を起こすが，それを解消する目的でウォールブ ロワが設置されている。しかし，蒸気噴霧によりスチー ムエロージョンやアッシュエロージョンが生じる。また,

* 第 58 回材料と環境討論会 (名古屋, 2011 年) および第 59 回材料 と環境討論会 (旭川, 2012 年) で一部発表

** 661-0974 尼崎市若王寺 3-11-20 (3-11-20 Nakouji, Amagasaki, 661 -0974 Japan)

*** ₹ 676-0082 高砂市兽根町 1049-3(1049-3 Sone-Cho, Takasago, 6760082 Japan)

† ₹ 592-0001 高石市高砂 3-69(3-69 Takasago, Takaishi, 592-0001 Japan)

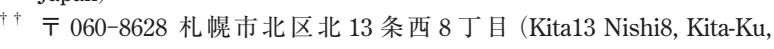
Sapporo, 060-8628 Japan)
燃焼室内は, 環境対策の一環により低 $\mathrm{O}_{2}$ 燃焼され, NOx の発生を抑制するが, 還元性雲囲気が生起し, 硫 化腐食の環境となっている。 それに加え，火炉側の管表 面に生じる繰り返し熱応力（スラグの付着脱落による局 部的な管表面温度変化，デスラッガ作動中や運転中の管 表面温度変化など）に起因する溝状腐食が報告されてい る $^{1)}$ 。その対策として, 従来, $\mathrm{Cr}_{3} \mathrm{C}_{2}-25 \mathrm{mass} \% \mathrm{NiCr}(\mathrm{Ni}$ : $\mathrm{Cr}=80$ mass $\%: 20$ mass\%, 以下 $\mathrm{Cr}_{3} \mathrm{C}_{2}-\mathrm{NiCr}$ とする) を溶射する方法が採用されているが，施工された溶射皮 膜は摩耗減肉, 腐食減肉, 割れ, 剥離などにより著しく 損傷を受け，2 年程度の使用でメンテナンスが必要とな っている2)。そこで，伝熱管の寿命延長を図るため，現 用の $\mathrm{Cr}_{3} \mathrm{C}_{2}-\mathrm{NiCr}$ 溶射皮膜の耐久性改善や新規溶射材料 の開発が期待される. それら改善, 新規開発材の実用化 には，まず実験室的な評価を行い，次いで実機での検証 が必要となるが, $\mathrm{Cr}_{3} \mathrm{C}_{2}-\mathrm{NiCr}$ の実機ボイラに適用するた めの評価プロセスを示した報告は見あたらない. $\mathrm{Cr}_{3} \mathrm{C}_{2}-$ $\mathrm{NiCr}$ の溶射方法は, $\mathrm{HVOF}^{3)-5)}$ および大気プラズマ溶射 (APS/Atmospheric Plasma Spraying : 以下 APS とする. $)^{6)-8)}$

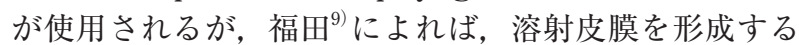


粒子間結合力の高い HVOF が適しているとされ，実機 における同一環境下で HVOF の方が APS に比べ 5 倍程 度, 耐摩耗性が優れている試験結果が示されている。富 田ら ${ }^{10)}$ は，減圧プラズマ溶射と HVOF の皮膜の硬さ特性 を皮膜組織から考察し, 減圧下では皮膜組織に導入され る気孔が少なく, 緻密性が向上し, 粒子間結合力が大き いことを報告している，一方，APS や HVOFにも溶射 火炎の出力が異なるいくつかの種類があるが，それらの 皮膜特性を比較した研究報告は見あたらず, 皮膜組織と の関連性が明らかにされていない。また，石炭燃焼ボイ ラを想定した還元性䨌囲気中の高温ガス腐食環境での溶 射皮膜の特性の報告 ${ }^{11)}$ や高温エロージョン特性の報告も

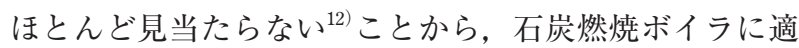
用するための溶射皮膜を総合的に評価する方法がない.

そこで，本報では溶射方法の異なる皮膜特性を気孔率 との関係から考察し, 実験室的な評価方法を確立するた め, 現用の $\mathrm{Cr}_{3} \mathrm{C}_{2}-\mathrm{NiCr}$ 溶射皮膜を HVOF と APS によっ て作製し, それら溶射皮膜の密着力, 高温硬さ, 耐摩耗, 耐高温腐食などの特性を評価した結果について述べた。 また，その結果に基づいて実験室評価法を提案した。

\section{2. 実 験 方 法}

\section{1 溶射方法と溶射条件}

溶射方法として HVOF は，スルザーメテコ社製溶射 機の DJ1000 およびDJ2700を使用した。また，皮膜特 性を比較するため, 島津工業社製溶射機の TPA1500を 使用し，APS 溶射を行った。（以下それぞれの溶射機で 作製した皮膜をHVOF（DJ1000）, HVOF（DJ2700）, APS（TPA1500）とする.） Table 1 に各々の溶射条件, 溶射材料の組成および平均粒径を示した。

\section{2 皮膜断面組織観察と気孔率測定}

溶射方法が決まれば溶射皮膜の断面組織と気孔率は適 正な溶射条件が保持されたかを判定する有力な手段とな る. 特に耐食・耐摩耗の観点からは皮膜の緻密性が重要 と考えられる．本報では以下の方法により溶射皮膜の断 面組織観察と気孔率測定を実施した。試験片は, 材質 $\mathrm{SS} 400$, 幅 $50 \mathrm{~mm}$, 長さ $50 \mathrm{~mm}$, 厚さ $4.3 \mathrm{~mm}$ の平板上 に HVOF（DJ1000，DJ2700）皮膜では，溶射距離 250

Table 1 Spraying condition, powder compositions and average particle sizes.

\begin{tabular}{|c|c|c|c|c|}
\hline \multicolumn{3}{|l|}{ HVOF } & \multicolumn{2}{|l|}{ APS } \\
\hline Spray system & DJ1000 & DJ2700 & Spray system & TPA1500 \\
\hline $\begin{array}{l}\text { Fuel : } \\
\text { LPG }\left(\times 10^{-5} \mathrm{Nm}^{3} \cdot \mathrm{s}^{-1}\right)\end{array}$ & $117 \sim 125$ & $117 \sim 125$ & Arc current (A) & $800 \sim 850$ \\
\hline Oxygen $\left(\times 10^{-5} \mathrm{Nm}^{3} \cdot \mathrm{s}^{-1}\right)$ & $500 \sim 517$ & $400 \sim 417$ & Arc voltage (V) & $30 \sim 35$ \\
\hline $\operatorname{Air}\left(\times 10^{-5} \mathrm{Nm}^{3} \cdot \mathrm{s}^{-1}\right)$ & $667 \sim 708$ & $583 \sim 633$ & $\operatorname{Argon}\left(\times 10^{-5} \mathrm{Nm}^{3} \cdot \mathrm{s}^{-1}\right)$ & $67 \sim 75$ \\
\hline $\begin{array}{l}\text { Powder feed gas } \\
\left(\times 10^{-5} \mathrm{Nm}^{3} \cdot \mathrm{s}^{-1}\right)\end{array}$ & 25 & 22 & $\begin{array}{l}\text { Powder feed gas } \\
\left(\times 10^{-5} \mathrm{Nm}^{3} \cdot \mathrm{s}^{-1}\right)\end{array}$ & 5.8 \\
\hline $\begin{array}{l}\text { Normal spray } \\
\text { distance }(\mathrm{mm})\end{array}$ & 250 & 250 & $\begin{array}{l}\text { Normal spray } \\
\text { distance }(\mathrm{mm})\end{array}$ & 150 \\
\hline
\end{tabular}

Producing company name Composition (mass\%) Average particle size $(\mu \mathrm{m})$

FUJIMI

INCORPORATED
23.5 mm（溶射機メーカ推奨值：以下標準溶射距離とする.） および $350 \mathrm{~mm}$, APS (TPA1500) 皮膜では, $150 \mathrm{~mm}$ （溶射機メーカ推奨值：以下標準溶射距離とする.）拈よ び $250 \mathrm{~mm}$ で溶射膜厚 $300 \mu \mathrm{m}$ を目標に作製した。その 皮膜の断面組織観察のために，試験片をマイクロカッタ ーで $1 / 2$ に切断し, エポキシ樹脂に埋め込み, $1 \mu \mathrm{m}$ 粒 径のダイヤモンド砥粒を用いてバフ研磨により表面を仕 上げた．その断面を光学顕微鏡により皮膜のクラック発 生の有無, 皮膜の浮き上がり，基材と皮膜界面のブラス 卜材の残存状況を観察し，欠陥の有無を調査した。また， 皮膜中の気孔および介在物は皮膜欠陥になるため，観察 写真ではいずれも黒色で現れ，両者の区別は判別できな いが，ここでは，混在割合を気孔率と定義し，光学顕微 鏡により倍率 105 倍に統一して撮影し, 画像処理ソフト (米国 National Institute of Health 社製 NHI Image Ver1. 62）を用いて画像解析により求めた.

次に，電子線マイクロアナライザ（EPMA）により溶 射材料の溶融状況, 溶射粒子間の密着状況, 気孔や介在 物（酸化物など）の分散状況を調査した。

\section{3 基材との皮膜密着強さ}

前項，皮膜組織と同様に溶射方法と溶射材料が決まれ ば，ほぼ所定の密着強さが得られるため, 現用品の HVOF で作製した $\mathrm{Cr}_{3} \mathrm{C}_{2}-\mathrm{NiCr}$ 溶射皮膜の密着力を測定 しておくことが重要であり，また前処理を含む不適切な 溶射条件が適用されたか否かの判定にも有効と考える.

溶射皮膜と基材（SS400）との常温での密着強さを引 張密着強さ試験およびせん断試験で評価した。両試験と もに応力負荷は，テスター産業社製（NTS-4700）引張 試験機を用いて荷重負荷速度 $1 \mathrm{~mm} / \mathrm{min}$. で測定した.

\subsection{1 引張密着強さ試験}

JIS H $8402\lceil$ 溶射皮膜の引張密着強さ試験方法」を参 考に溶射皮膜面に接着剂を塗布し, 引張用治具に固定し て実施した。その模式図を Fig. 1 に示す。試験片は，JIS に準拠して作製し，HVOF（DJ2700）皮膜とAPS （TPA1500）皮膜について，溶射距離が密着強さに及ほ す影響を調査した，溶射距離は，標準溶射距離と標準溶 射距離 $+100 \mathrm{~mm}$ の 2 条件で引張密着強さを評価した.

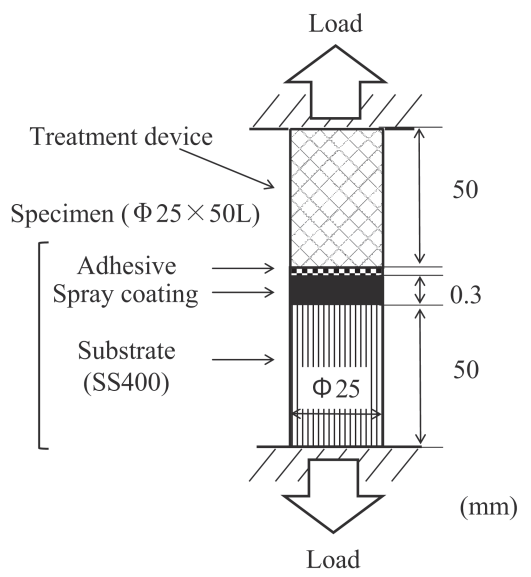

Fig.1 Schematic diagram of tensile adhesive strength test for thermal sprayed coatings. 


\subsection{2 せん断試験}

溶射皮膜の密着強さは, 皮膜または皮膜 / 基材界面で の破壊応力が測定されるが, HVOF (DJ1000, DJ2700) 皮膜では, 測定する溶射皮膜と基材界面より接着剂が先 に破壊（引張密着強さ：約 $90 \mathrm{MPa}$ ）する場合があるた め, 接着剤強度を超える密着強さに対応する測定方法と して，接着剂を使用しない，せん断力を溶射皮膜と基材 界面に負荷するせん断試験を実施した. Fig. 2 にせん断 試験の模式図を示す。試験片は, SS400の基材に厚さ $500 \mu \mathrm{m}$ の溶射皮膜を施工し，平面研削盤により幅 24 $\mathrm{mm} \times$ 長さ $1.5 \mathrm{~mm}$ の溶射皮膜を残した試験片を作製し た.

\section{4 ヒートサイクル試験}

実機ボイラに施工された溶射皮膜の割れや剥離などの 損傷は, 起動停止や負荷変動などに伴い基材と溶射皮膜 の熱膨張率差に伴う熱応力が加わることが一因と考えら れる. そのため, 溶射皮膜に実機運用範囲と同程度のヒ ートサイクルを負荷して皮膜の健全性をヒートサイクル 試験で評価した。

試験片は, ボイラ管（材質火 STBA21S, 外径 $27 \mathrm{~mm}$, 内径 $22 \mathrm{~mm}$ ）を長さ $450 \mathrm{~mm}$ に切断加工後, その表面に 溶射皮膜厚さを $325,530,620,720 \mu \mathrm{m}$ に施工し長さ $30 \mathrm{~mm}$ に切断して作製した。試験は電気炉大気中にて, 室温 $\rightarrow 500^{\circ} \mathrm{C}$ (昇温速度 $0.17^{\circ} \mathrm{C} \mathrm{s}^{-1}, 20$ 分間保持) $\rightarrow$ 炉 外に取り出して大気冷却 $\left(500^{\circ} \mathrm{C} \rightarrow\right.$ 室温, 冷却速度約 $\left.0.18^{\circ} \mathrm{C} \mathrm{s}^{-1}\right)$ のヒートサイクルを 10 サイクル実施した. サイクル試験後の皮膜の割れや剥離を皮膜表面にエ夕ノ ールを噴霧して損傷を確認し, 損傷箇所を管周方向に切 断して光学顕微鏡により皮膜の健全性を評価した.

\section{5 皮膜の高温硬さ測定}

現用品の $\mathrm{HVOF}$ で作製した $\mathrm{Cr}_{3} \mathrm{C}_{2}-\mathrm{NiCr}$ 溶射皮膜の常 温硬さはおよそ $960 \mathrm{Hv}$ 程度 ${ }^{13)}$ であるが，ボイラ伝熱面 へ耐摩耗皮膜として利用する場合, 伝熱管表面温度での 皮膜硬さ (保持) が重要となるものの, 公表されたデー 夕は少なく本報では以下, 日本工学製高温顕微硬度計 (QM 型) でビッカース硬さを JIS Z 2244 に準じて 10 点 測定し, 平均值で評価した。試験片は, 材質 SS400, 幅 $50 \mathrm{~mm}$, 長さ $50 \mathrm{~mm}$, 厚さ $4.3 \mathrm{~mm}$ の平板上に溶射皮膜

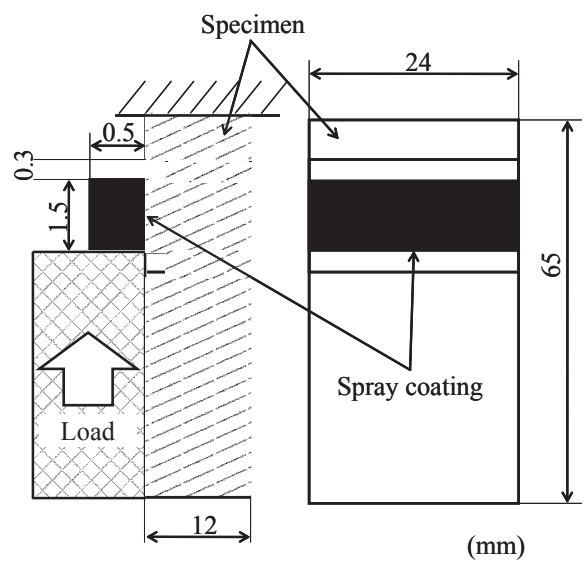

Fig.2 Schematic diagram of shear stress loading test of thermal sprayed coatings.
厚さ $300 \mu \mathrm{m}$ を目標に施工し, 幅 $5 \mathrm{~mm}$, 長さ $10 \mathrm{~mm}$, 厚さ $4.6 \mathrm{~mm}$ に切断して作製した。測定条件は, $4 \times 10^{-3}$ $\mathrm{Pa}$ 真空䨌囲気中にて室温および $100 \sim 500^{\circ} \mathrm{C}$ まで $100^{\circ} \mathrm{C}$ 間隔で加熱速度 $20^{\circ} \mathrm{C} / \mathrm{min}$, 保持時間 5 分, 試験荷重 50 $\mathrm{g}$, 荷重負荷時間 30 秒で測定した.

\section{6 耐摩耗特性試験}

\subsection{1 摺動摩耗試験}

現用品の $\mathrm{HVOF}$ で作製した $\mathrm{Cr}_{3} \mathrm{C}_{2}-\mathrm{NiCr}$ 溶射皮膜の基 礎的な摩耗特性を把握するため，常温での摺動摩耗試験 を実施した。スガ試験機社製スガ摩耗試験機 NUS-ISO3 を用いて，試験片に\#320エメリー紙を $29.4 \mathrm{~N}$ の試験荷 重で押し当てて，摺動回数 400 回ごとに試験片の重量変 化を測定し, 1600 回まで実施した。耐摩耗性は，減量に よって評価した。試験片は材質 SS400, 幅 $50 \mathrm{~mm}$, 長さ $50 \mathrm{~mm}$, 厚さ $4.3 \mathrm{~mm}$ の平板上に膜厚 $500 \mu \mathrm{m}$ の溶射皮 膜を施工して作製した。

\section{6 .2 高温エロージョン試験}

前述のように実機では噴射蒸気に巻き込まれた燃焼灰 の衝突摩耗（エロージョン）が想定される．溶射皮膜は 溶融または未溶融粒子の積層する成膜過程より, 積層粒 子間の密着力に問題があり, ブラストエロージョン型の 摩耗に弱点を持つと言われている ${ }^{14)}$. 特に高温環境では, 皮膜特性の変化に対応してどの程度の特性を示すのか現 用品でも不明な点が多い。本報では, HVOF (DJ1000) を用いて，摩耗材としてホワイトアルミナ（WA\#180： 平均粒径 $70 \mu \mathrm{m}$ ) を利用して高温エロージョン試験を実 施した。試験片は，ボイラ管（材質火 STBA21S，外径 $27 \mathrm{~mm}$, 内径 $22 \mathrm{~mm}$ ) を長さ $75 \mathrm{~mm}$ に加工し, その表 面に溶射膜厚 $500 \mu \mathrm{m}$ を目標に溶射施工して作製した。 試験片の温度は, 試験面（溶射機側）の試験片下部から 直径 $1.8 \mathrm{~mm}$, 深さ $7 \mathrm{~mm}$ のキリ孔を設けて熱電対によ り測定し, 実機使用環境である $450^{\circ} \mathrm{C}$ 目標とするため, 次の試験手順で実施した。試験開始前に試験片の予備加 熱を溶射ガンからの燃焼火炎で加熱を行い, 試験片温度 が $400^{\circ} \mathrm{C}$ に到達した後, 溶射ガンにホワイトアルミナを 供給して試験を開始した. Fig. 3 に高温エロージョン試 験の模式図および溶射ガンの移動パターンを示す。溶射 ガンは, 幅 $60 \mathrm{~mm} \times$ 高さ $30 \mathrm{~mm}$ の範囲を高さ方向に 3 $\mathrm{mm}$ ピッチで移動させて Table 2 の試験条件でブラスト を行った。耐摩耗性は, 試験片の減量をブラスト面積で 除して試験片の単位面積あたりの減量を算出して評価し た.
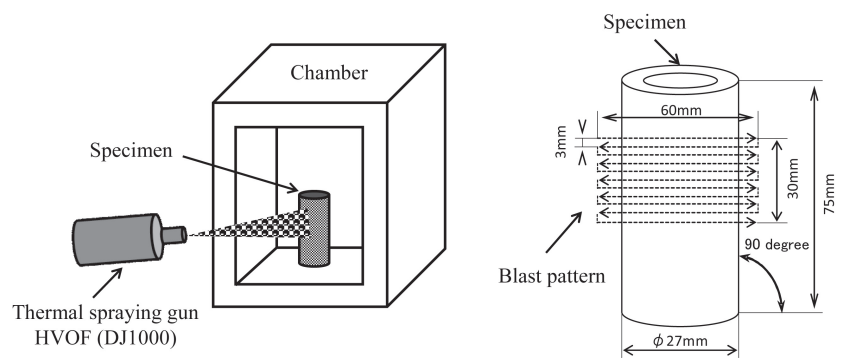

Fig.3 Schematic diagram of high temperature erosion test and blast pattern. 
Table 2 Erosion test condition.

\begin{tabular}{|c|c|}
\hline Test element & $\begin{array}{c}\text { Temperature } \\
\left(\fallingdotseq 450^{\circ} \mathrm{C}\right)\end{array}$ \\
\hline Testing system & DJ1000 \\
\hline Spray distance & $300 \mathrm{~mm}$ \\
\hline Specimen size & $\Phi 27 \mathrm{~mm} \times 75 \mathrm{~mm}$ \\
\hline Specimen angle & 90 degree \\
\hline $\begin{array}{c}\text { Abrasive } \\
\text { ( White alumina })\end{array}$ & WA $\# 180$ \\
\hline Amount of blast & $0.75 \sim 0.83 \mathrm{~g} / \mathrm{s}$ \\
\hline Traverse speed & $20 \mathrm{~mm} / \mathrm{s}$ \\
\hline Number of cycles & 3 \\
\hline
\end{tabular}

\section{7 高温硫化腐食試験}

実機では低 $\mathrm{O}_{2}$ 燃焼の影響で還元性䨌囲気が 生起し, 硫化腐食の発生が想定されるため, 新 たに適用される耐食・耐摩耗溶射皮膜には耐硫 化腐食性の付与も重要な項目である。ここでは, 耐高温硫化腐食性評価の一環として現用品の硫 化腐食特性を次の $\mathrm{H}_{2}-\mathrm{H}_{2} \mathrm{~S}$ 硫化腐食試験で調查した。試 験片は，ボイラ管（材質火 STBA21S，外径 $27 \mathrm{~mm}$, 内 径 $22 \mathrm{~mm}$ ）を長さ $20 \mathrm{~mm}$ に切断加工し, その表面に溶 射膜厚 $300 \mu \mathrm{m}$ を施工後 $1 / 2$ に切断したものと, 無溶射 施工のものを比較材として供試した。試験には, Fig. 4 に示した試験装置を使用した。試験温度 $\left(500^{\circ} \mathrm{C}\right)$ まで の昇温中は $\mathrm{Ar}$ ガスを通気し, 試験温度に到達後炉内温 度が安定するまで 1 時間保持した後, Ar ガス雾囲気か ら $\mathrm{H}_{2}-1 \mathrm{vol} \% \mathrm{H}_{2} \mathrm{~S}$ ガスの試験ガスに切り替えて 5 時間保 持, その後 $\mathrm{Ar}$ ガスに切り替え, 炉冷にて $200^{\circ} \mathrm{C}$ まで降 温するサイクルを 5 回繰返し，合計 25 時間の暴露試験 を行った。

\section{3. 試験結果と考察}

\section{1 皮膜断面組織と気孔率 \\ 3.1.1 皮膜組織}

\subsubsection{1 光学顕微鏡観察}

Fig. 5 に溶射距離の異なる溶射皮膜の断面組織の観察 結果を示した。(a)，(b)，(c) は各溶射方法の標準溶射

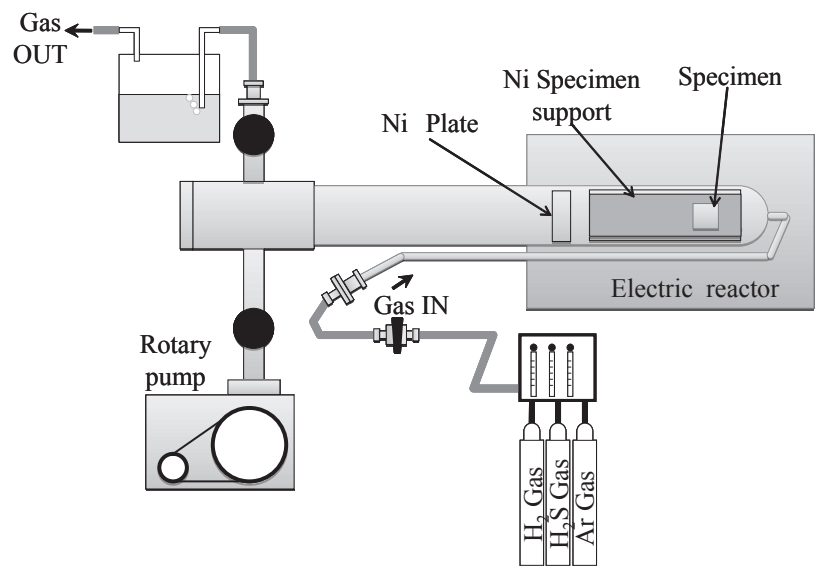

Fig.4 Schematic diagram of equipment for high temperature sulfidation test.

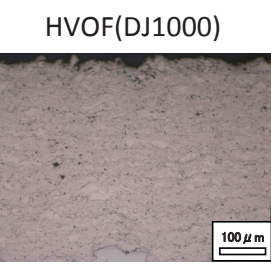

(a)
HVOF(DJ2700)

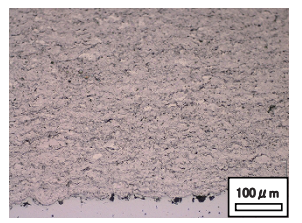

(b)

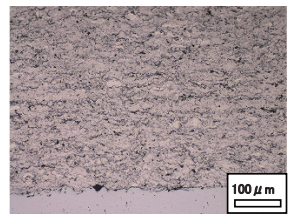

(d)
APS (TPA1500)

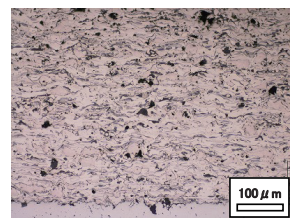

(c)

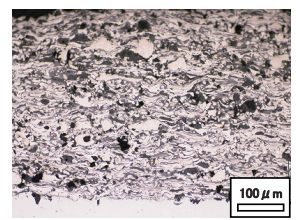

(e)
Fig.5 Cross-sectional microstructure of sprayed coating of $\mathrm{Cr}_{3} \mathrm{C}_{2}-\mathrm{NiCr}$. (a) HVOF coating by DJ1000 ; Spray distance : $250 \mathrm{~mm} \mathrm{(b)}$ HVOF coating by DJ2700 ; Spray distance : $250 \mathrm{~mm}$ (c) APS coating by TPA1500 ; Spray distance : $150 \mathrm{~mm} \mathrm{(d)} \mathrm{HVOF} \mathrm{coating}$ by DJ2700 ; Spray distance : $350 \mathrm{~mm}$ and (e) APS coating by TPA1500 ; Spray distance: $250 \mathrm{~mm}$.

距離で溶射した皮膜組織で，(d)，（e）は標準溶射距離 より $100 \mathrm{~mm}$ 遠方から溶射した皮膜組織である。標準溶 射距離で溶射した皮膜の組織は，いずれも皮膜中に割れ 等は存在せず基材と密着して抢り, 皮膜 / 基材界面に気 孔や皮膜浮き上がり等の異常は認められなかった。また， 皮膜割れについても観察されず組織観察上成膜に問題は ないものと判断できる.

標準溶射距離で作製した HVOF（DJ1000, DJ2700）皮 膜は，やや不明確であるが，僅かに黒色介在物または空 孔が存在し, 皮膜中に未溶融溶射粒子状の塊状粒子が認 められるが，皮膜自体は緻密であった。また，HVOF （DJ2700）皮膜は HVOF（DJ1000）皮膜で見られた塊状 粒子はより細粒化し緻密な組織を示したが，微細な黒色 介在物が全体に分布していた。

一方，APS 溶射皮膜は溶射粒子が偏平したラメラ状の 組織となり, やや大きな黒色介在物または空孔が皮膜全 体に分布していた。

なお，溶射距離を遠方とした (d)，(e) では HVOF (DJ2700), APS とも介在物や空孔が増加, 粗大化する傾 向にあったが, 特にAPS は顕著であった.

\subsubsection{EPMA 分析結果}

Fig. 6 に HVOF（DJ2700）皮膜と APS（TPA1500）皮 膜の EPMA による $\mathrm{Ni}, \mathrm{Cr} ， \mathrm{C} ， \mathrm{O}$ の分布を調查した結 果を示した。

HVOF（DJ2700）皮膜では島状の $\mathrm{NiCr}$ を埋めるよう

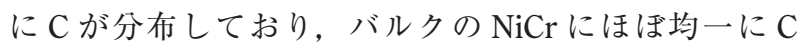
（炭化物）が分散している状況がうかがえた。また，層 全体に O が分布しているが，所々，塊状に濃度が高くな っており空孔の存在を示唆していた。

一方, APS 皮膜はラメラ状組織の $\mathrm{NiCr}$ の分布と C の 分布は大まかに分離できるが, その境界は不明確で, 相 互に拡散している状況がうかがえた。また，Oは $\mathrm{NiCr}$ の分布と完全に一致しないものの, 皮膜全体に鮮明に分 布しており HVOF（DJ2700）皮膜に比較し, 皮膜中に酸 化物が多く存在することが確認できた。また，その酸化 物近傍で特に $\mathrm{O}$ 濃度が高い位置が存在しており, これら 


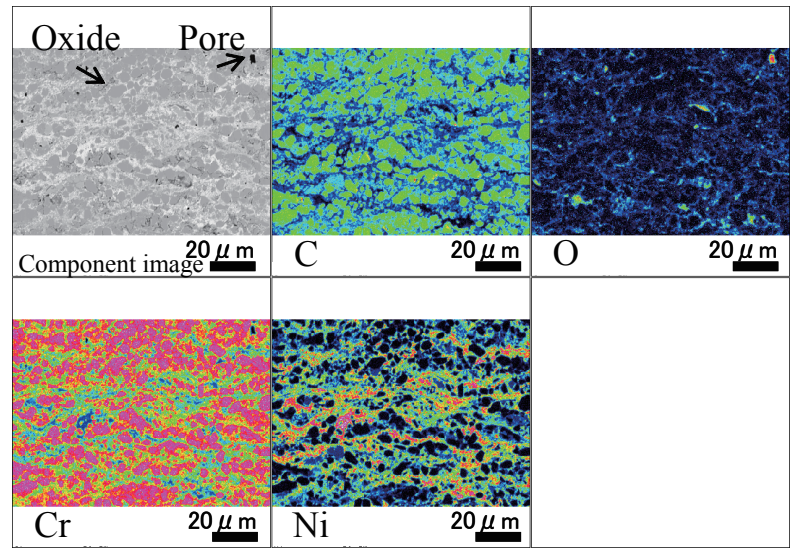

(a)

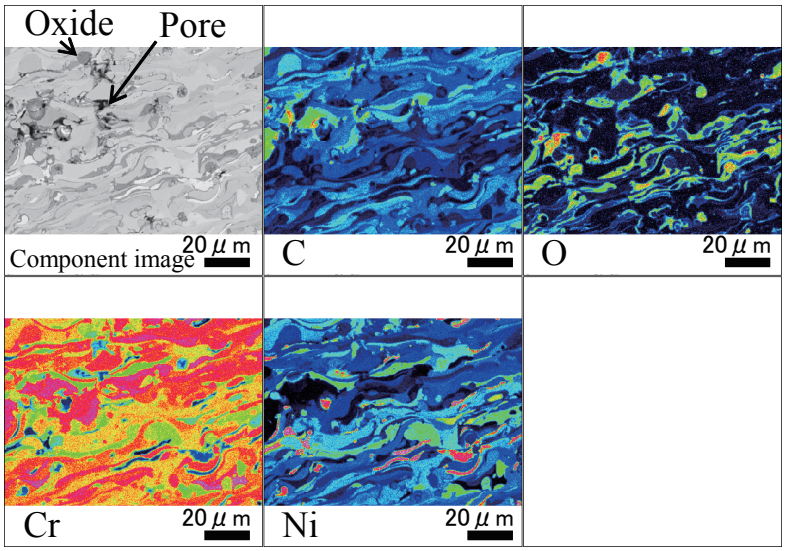

(b)

Fig.6 EPMA elemental mapping. (a) HVOF coating by DJ2700 and (b) APS coating by TPA1500.

はSEM 写真の結果と併せて, 酸化物近傍に存在する空 孔と確認された。

これら溶射皮膜組織の相違は HVOF と APS 溶射の違 ( ${ }^{15)}$ に起因するものであると考えられる。すなわち HVOF は火炎温度 $3000^{\circ} \mathrm{C}$ 前後, $20 \sim 50 \mu \mathrm{m}$ 程度の溶射 粒子を飛行速度 $300 \sim 600 \mathrm{~m} \cdot \mathrm{s}^{-1}$ 前後で溶射するのに対 し, APS は火炎温度が $10000^{\circ} \mathrm{C}$ 近くに達し, $40 \sim 150 \mu$ $\mathrm{m}$ 程度の溶射粒子を飛行速度 $150 \sim 300 \mathrm{~m} \cdot \mathrm{s}^{-1}$ 前後で溶 射するため，APS 溶射は溶射時の熱影響が大きく，溶射 粒子の酸化や $\mathrm{Cr}_{3} \mathrm{C}_{2}$ と $\mathrm{NiCr}$ の相互拡散が進行したもの と考えられる.

$\mathrm{Cr}_{3} \mathrm{C}_{2}-\mathrm{NiCr}$ 溶射皮膜の高温耐摩耗性は, 融点（1915 $\left.{ }^{\circ} \mathrm{C}\right)$ が高く硬度が大きい $\mathrm{Cr}_{3} \mathrm{C}_{2}$ の存在に期待しており, 組織調査の結果からも相互拡散等による $\mathrm{Cr}_{3} \mathrm{C}_{2}$ 消耗（変 化）の少ないHVOF 溶射が優れていることが確認され た.

\subsection{2 気孔率}

Fig. 5 の溶射皮膜の光学顕微鏡写真から画像解析ソフ トにより気孔率を解析し, 結果を Fig. 7 に示した。標準 溶射距離の HVOF（DJ1000）皮膜および HVOF（DJ2700） 皮膜では気孔率は $1 \%$ 程度で, 溶射距離を長くした HVOF（DJ2700）皮膜でも気孔率はやや大きくなる程度 で大きな差は見られなかった。一方，APS（TPA1500） 皮膜は, HVOF（DJ1000, DJ2700）皮膜に比べ標準溶射 距離で $2 \%$ を超え, 気孔率が 2 倍以上, 標準溶射距離 + $100 \mathrm{~mm}$ の場合では $4 \%$ を超え気孔率が 4 倍程度であっ

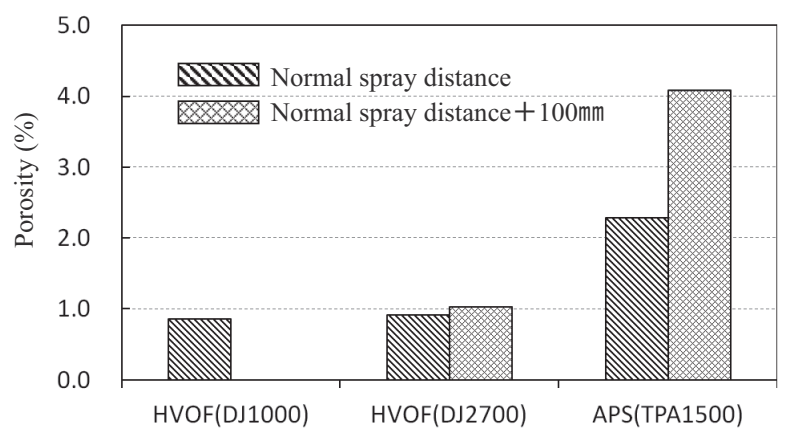

Fig.7 Porosity of thermal sprayed coatings.
た.

これら気孔率の違いは，前述のようにHVOF では低 温で比較的粒径が小さな溶射粒子を高速で溶射面に衝突 させるため皮膜が緻密化したのに対し，APS は高温でや や大きな溶射粒子を十分に溶融させて溶射面に衝突させ るため, 空孔の巻き込みや酸化物が多くなり, 結果とし て気孔率が大きくなったと考えられる.

\section{2 皮膜の高温硬さ}

高温硬さ測定結果を Fig. 8 に示す。硬さの平均值を棒 グラフで示し, 測定データの最大值および最小值を棒グ ラフ上に示した。いずれの溶射皮膜も温度上昇とともに 硬さが低下する傾向を示した. 測定データのバラツキは, APS（TPA1500）皮膜と比較して HVOF の方が大きい傾 向を示した。これは, HVOF（DJ1000, DJ2700）皮膜中 での未溶融の $\mathrm{Cr}_{3} \mathrm{C}_{2}$ 粒の分布状態に起因している.すな わち，硬さ測定に用いる圧子の扦入位置に $\mathrm{Cr}_{3} \mathrm{C}_{2}$ 粒の濃 度が高ければ高い硬度になるが, $\mathrm{NiCr}$ の金属成分や気 孔の濃度が高い領域では低い硬度を示す。

実機の使用温度域である $300^{\circ} \mathrm{C}$ 以上で要求される硬さ はバラツキを考虑しても HVOF（DJ2700）皮膜の方が HVOF（DJ1000）皮膜より高いと判断できる.

一方, APS (TPA1500) 皮膜ではHVOF（DJ1000， DJ2700）皮膜に比較してもともと硬度が低いのに加え, $\mathrm{Cr}_{3} \mathrm{C}_{2}$ および $\mathrm{NiCr}$ ともに溶融したラメラ組織を呈してい ることからバラッキが小さくなったものと考えられる.

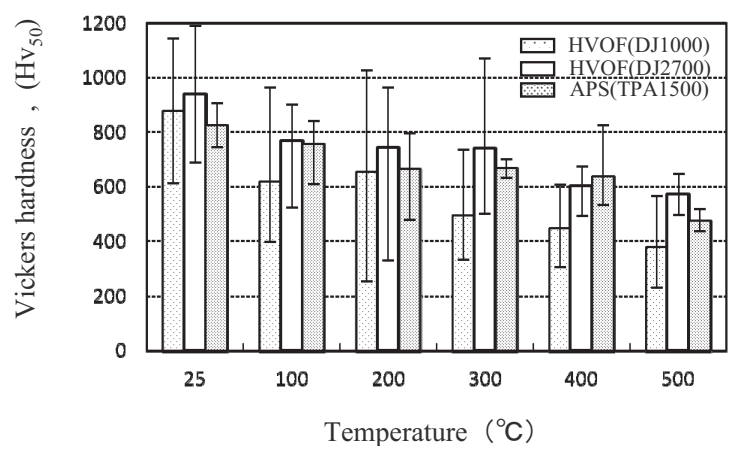

Fig.8 Relationship between hot Vickers hardness and temperature in thermal sprayed coatings. 


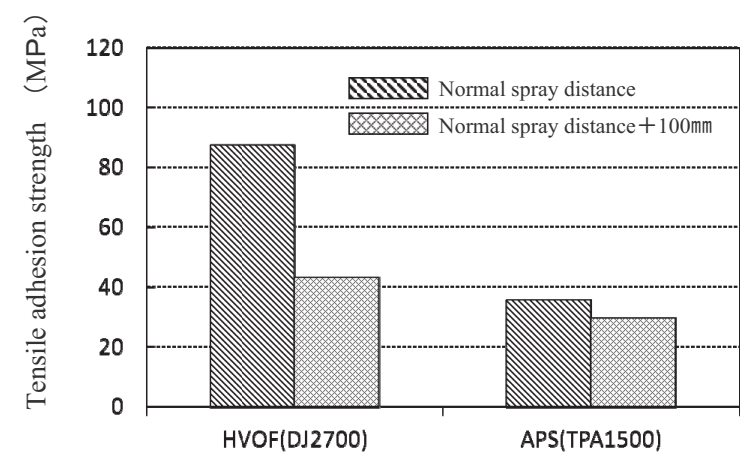

Fig.9 Influence of spray distance on tensile adhesion strength.

\section{3 基材との皮膜密着強さ}

\subsection{1 引張密着強さ試験}

引張密着強さの試験結果を Fig. 9 に示す。標準溶射距 離の場合における HVOF (DJ2700) 皮膜と APS （TPA1500）皮膜を比較すると，HVOF（DJ2700）皮膜 は 87.5 MPaであり, APS（TPA1500）皮膜（35.7 MPa） と比較して約 2.5 倍の引張密着力を示した。一方, 標準 溶射距離 $+100 \mathrm{~mm}$ とした場合では, HVOF（DJ2700） 皮膜は $43.3 \mathrm{MPa}$ であり, APS（TPA1500）皮膜の 29.8 $\mathrm{MPa}$ と約 1.5 倍の密着力の差であった.

また, 標準溶射距離と標準溶射距離 $+100 \mathrm{~mm}$ との密 着力の比較では, HVOF (DJ2700) 皮膜では半減し, APS（TPA1500）皮膜では約 17\%減少したが，いずれの 場合でも, 皮膜の剥離は皮膜 / 基材界面で起きていた。

以上, 皮膜の引張密着力は APS 皮膜に比較して HVOF（DJ2700）皮膜が大きいことが確認されたが, HVOF（DJ2700）皮膜の密着力が大きいのは，前述のよ うに，未溶融に近い硬い小粒子が高速で基材に衝突し積 層されるためと考えられる。

また，皮膜の密着性は，溶射距離を標準条件 (250 $\mathrm{mm}$ ) より $100 \mathrm{~mm}$ 長くすると APS, HVOF（DJ2700） とも大幅に低下することが判明した。この原因として溶 射粒子の基材への衝突速度低下や溶射中の酸化等による 介在物の増加などが考えられる。この溶射距離と皮膜密 着力の関係は実機伝熱面へ手動で溶射する場合を想定す ると大変重要であるが, 標準溶射距離に対し現場で+ （あるいは - ） $100 \mathrm{~mm}$ の範囲で溶射距離を確保するの は困難なため, 実用時工場施工皮膜に比較し現場施工皮 膜の劣化が早いケースがしばしば発生する一因にもなっ ているのではないかと推定される。これらの結果を基に 今後はさらに距離範囲（標準溶射距離土）と溶射皮膜の 関係を把握していくことが必要と考える.

なお，本報では溶射直後（未使用品）の皮膜密着性に ついて評価したが，実用時を想定すると経年的な劣化を どのように評価するか, また長時間加熱後の溶射皮膜の 密着性の測定や, 川原 ${ }^{16)}$ が実施しているような炉内で の直接伝熱面溶射皮膜の密着力測定の検討も必要と思わ れる。

\subsection{2 せん断試験}

せん断試験結果を Fig. 10 に示す. 前記の引張密着力 と同様に HVOF 皮膜は APS 皮膜より密着力が高くなる 傾向が得られた. HVOF 皮膜のせん断強さは, 高出力の HVOF (DJ2700) 皮膜で $104 \mathrm{MPa}$, 低出力の HVOF

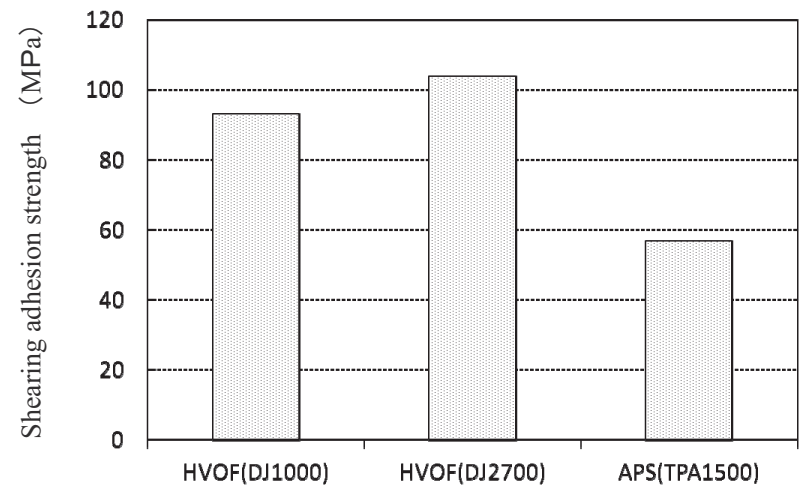

Fig.10 Shearing adhesion strength of coatings prepared by HVOF and APS spraying.

（DJ1000）皮膜で $93 \mathrm{MPa}$ ，APS（TPA1500）皮膜で 56.8 $\mathrm{MPa}$ であった。各試験片の皮膜の剥離は，皮膜 / 基材 界面で起きていた，本試験方法は，引張試験のように接 着剤に由来する試験結果のバラツキを排除するため実施 したものであるが，皮膜剥離機構は本質的に異なると考 えられる．また，溶射ハンドブックによる溶射皮膜の密

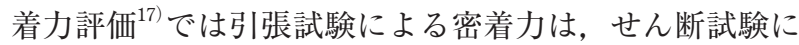
よる密着力の方がやや大きくなる傾向があり，今回の試 験結果とよく一致している.

溶射皮膜の密着力を比較的簡便な引張試験で評価する か，あるいは試験片加工にやや難点のあるせん断試験で 評価するかは難しい選択であるが，前述のように溶射条 件 (溶射距離) と皮膜密着性の正確なデー夕を得るには 試験結果にバラツキの少ないせん断試験が適当と判断し た.

\section{4 ヒートサイクル試験}

Fig. 11 にHVOF（DJ2700）皮膜に対するヒートサイ クル試験後の試験片外観および溶射層の断面組織を観察 した結果を示す。観察位置は, 試験片表面にエタノール を噴霧し，目視によりクラック（き裂）が認められた位 置で切断した周方向の断面とした．溶射皮膜の剥離や脱 落は認められなかったが, 膜厚が $500 \mu \mathrm{m}$ を超えるとク ラックが発生しやすい傾向にあった。また, クラックは 基材まで貫通しており，燃焼ガスや石炭灰中の腐食性成 分がクラック内に侵入すると基材との界面で腐食が進行 し, 溶射皮膜の剥離を促進する可能性を示唆していた。

一方，APS (TPA1500) 皮膜は，すべての試験片でク ラックは認められなかった。このことから，ヒートサイ クルによる皮膜割れに対する感受性は気孔率と相関があ り, 気孔率の高い皮膜は, 引張密着強さも小さく, 粒子 間結合力が弱いため, 気孔が応力に対して緩衝作用を及 ぼし, 結果として皮膜組織に勒性を与えていると考えら れる。

以上，ヒートサイクル試験では，実用上最も問題とな る溶射皮膜とクラック発生の関係を把握でき，今後，高 温耐食・耐摩耗溶射皮膜を選定する上での最重要試験で あると考える。 


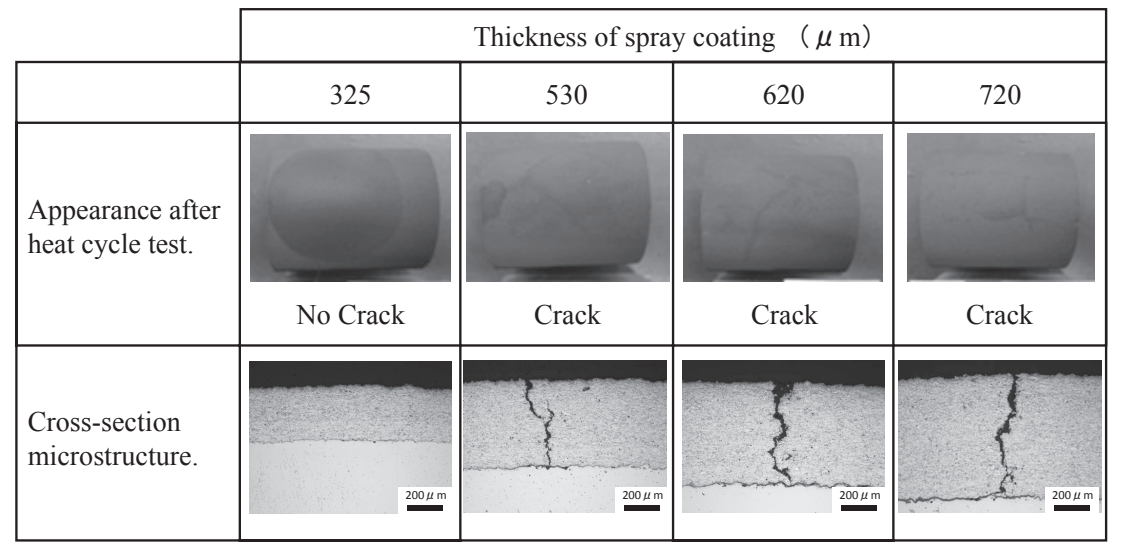

Fig.11 Receptivity to crack of thermal sprayed coatings after heat cycle test.

試験片の減肉深さ $\mathrm{t}=\mathrm{W} / \rho \mathrm{A}$ ここで,

$\mathrm{W}$ ：試験片の減量

$\mathrm{A} ：$ ブラスト面積

$\rho: \mathrm{CrC}-\mathrm{NiCr}$ 溶射皮膜の 比重 $=7.16$

$\left(\mathrm{Cr}_{3} \mathrm{C}_{2}\right.$ の比重 ${ }^{18)}=6.68,80 \mathrm{Ni} 20 \mathrm{Cr}$ の比重 $=8.6$ より算出）とする.

その結果, 試験後の減肉深さ (t) は, HVOF $(\mathrm{DJ} 1000)=528 \mu \mathrm{m}$, HVOF $(\mathrm{DJ} 2700)=434 \mu \mathrm{m}$, APS $=767 \mu \mathrm{m}$ に相当する. 初期皮膜 厚さから試験後の減肉深さを差し 引くと $\operatorname{HVOF}(\mathrm{DJ} 1000)=-43 \mu \mathrm{m}$, HVOF $(\mathrm{DJ} 2700)=116 \mu \mathrm{m}$ および $\mathrm{APS}=-217 \mu \mathrm{m}$ となり, 試験後

\section{5 耐摩耗, 耐エロージョン特性評価}

\subsection{1 摺動摩耗}

摺動試験結果を Fig. 12 に示す。いずれの皮膜におい ても試験回数の増加とともに直線的に減量する傾向を示 した. HVOF (DJ1000, DJ2700) 皮膜は APS (TPA1500) 皮膜と比較すると $1 / 3$ 程度の摺動摩耗量を示した. これ は, Fig. 7 の気孔率から分かるように, HVOF（DJ1000, DJ2700）皮膜は $0.91 \%$ 以下と APS（TPA1500）皮膜よ り 2 倍以上気孔率が小さく, 緻密な皮膜が形成し, 粒子 間結合力が高い皮膜が形成されているためと考えられ る. また, 高硬度の $\mathrm{Cr}_{3} \mathrm{C}_{2}$ 粒子が未溶融で均一に分散し ているために平面における耐摩耗性が向上していること も影響していると考えられる。

\section{5 .2 高温エロージョン}

Fig. 13 に高温エロージョン試験後の単位面積あたりの 減量結果を示す。各試験片の減量ならびにブラスト面積 は HVOF (DJ1000) 皮膜 $=3.1358 \mathrm{~g}\left(8.30 \mathrm{~cm}^{2}\right), \mathrm{HVOF}$ $(\mathrm{DJ} 2700)$ 皮膜 $=2.5958 \mathrm{~g}\left(8.36 \mathrm{~cm}^{2}\right)$, APS（TPA1500） 皮膜 $=4.5483 \mathrm{~g}\left(8.29 \mathrm{~cm}^{2}\right)$ であった。すなわち, APS （TPA1500）皮膜は HVOFで作製された皮膜より摩耗す る傾向がある。試験後の各試験片の表面を目視により観 察すると, HVOF (DJ2700) 皮膜のみ残存が確認できた.

また, 単位面積あたりの減量結果から試験片の減肉深 さを次式により算出した。

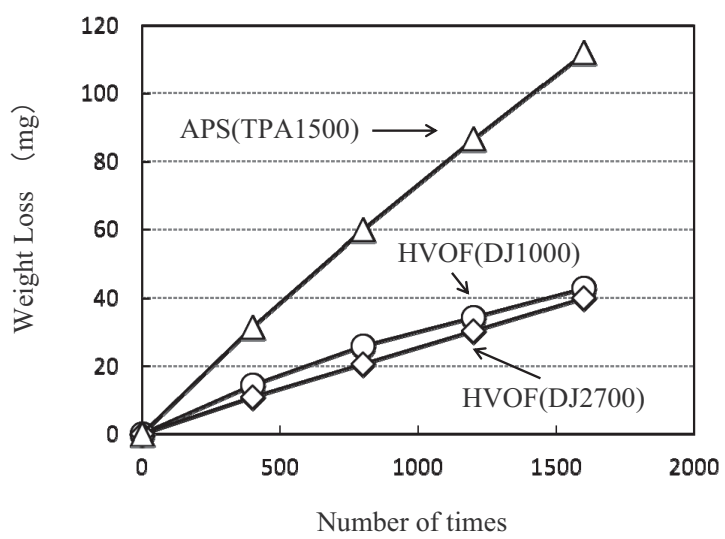

Fig.12 Weight loss after in abrasive wheel wear test for sprayed coatings prepared by HVOF and APS.
の目視よる観察結果と一致し，気孔率が小さい，緻密な 皮膜特性に相関があると認められる.

このことは, 常温での摩耗機構ではあるが,

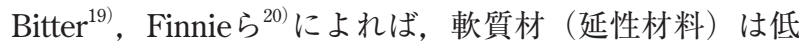
角度側の依存性を示し, 材料表面の一部が切削除去され ることによる摩耗機構に対し，硬質材（脆性材料）は高 角度側の依存性を示し, 衝突粒子による材料表面の変形 が進行する摩耗機構であるとし, Hutchings ${ }^{21)}$, 岡崎ら ${ }^{22)}$ はそれを支持している。

本試験は, 試験片温度 $450^{\circ} \mathrm{C}$ を目標に噴射距離を調節 し， $400^{\circ} \mathrm{C} \sim 480^{\circ} \mathrm{C}$ の範囲で実機の伝熱管表面温度域で実 施したもので，高温硬さ特性で明らかなように，溶射皮 膜も温度上昇に伴い軟化し，かつ，噴射蒸気の直接的影 響（噴射蒸気は温度 $593 \mathrm{~K}\left(320^{\circ} \mathrm{C}\right)$ ，流速 $604 \mathrm{~m} \cdot \mathrm{s}^{-1}$ で 極めて高速流）に加え，噴射蒸気に巻き込まれて飛来す る燃焼灰の大きさ，重量，衝突角度ならびに速度は一定 でなく, 実機現象は極めて複雑であるが, 切削型摩耗機 構ではないかと考える.

しかしながら，このような実機条件を再現するには大 掛かりな装置が必要となる. 本試験は高温でのブラスト エロージョン特性を把握するため新規に採用したもの で, 試験温度の制卸やブラストに用いる衝突粒子径, 衝 突速度，高温硬さとの関係など実機との対応でいくつか の検討すべき課題もあるが, 高温域で耐食・耐摩耗溶射 皮膜のブラストエロージョン特性を把握する試験方法と して有用と考える。

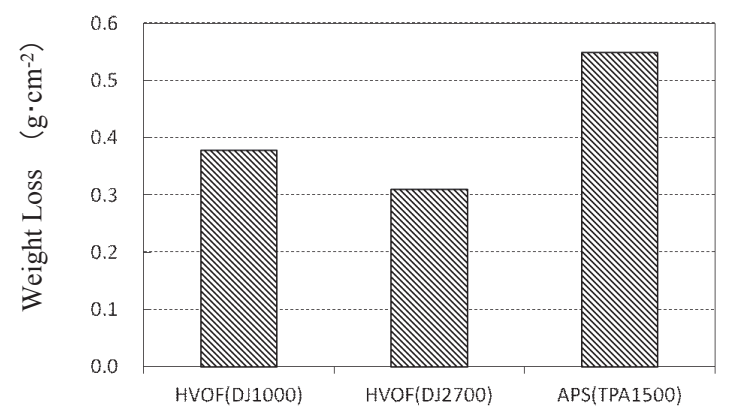

Fig. 13 Weight loss after high temperature erosion test for sprayed coatings prepared by HVOF and APS. 


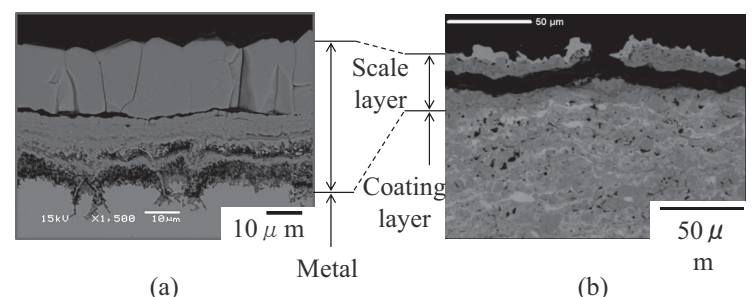

Fig.14 Cross-sectional microstructures of sulfidized STBA21S (a) without and (b) with sprayed coating of $\mathrm{Cr}_{3} \mathrm{C}_{2}-$ $\mathrm{NiCr}$.

\section{6 高温耐食性評価}

$\left(\mathrm{H}_{2}-\mathrm{H}_{2} \mathrm{~S}\right.$ ガスによる高温硫化腐食試験 $)$

Fig. 14 に試験後の断面組織観察結果を示す. STBA21S は $40 \sim 50 \mu \mathrm{m}$ の顕著な腐食スケール（硫化物 層）が生成している ${ }^{9)}$ のに対し，HVOF 溶射皮膜は表層 に $20 \mu \mathrm{m}$ 程度の腐食変質層が生成している程度で溶射 層内への S 分の侵入も見られなかった．このことは，気 孔率が小さく, 緻密な組織となっているため, 皮膜中に 腐食性ガスが侵入できなかったことを示唆している。そ の腐食変質層の腐食状況をエネルギー分散型 $\mathrm{X}$ 線分析 (EDS) により元素分布を調査した結果を Fig. 15 に示し たが，試験片表面にNiリッチ層を形成しており，その 直下に Crリッチな硫化物が層状に形成していた。これ らは，溶射皮膜と試験ガスの反応によって形成された腐 食層である。以上のように現用の $\mathrm{Cr}_{3} \mathrm{C}_{2}-\mathrm{NiCr}$ は基材で あるSTBA21Sに比較して優れた耐高温硫化腐食性を有 することが確認された.

本試験方法は石炭燃焼ボイラへ適用する耐食・耐摩耗 溶射皮膜の耐食性評価に活用していく所存である.

\section{4. 結言}

微粉炭燃焼ボイラにおける高温硫化腐食と摩耗により 複合損傷対策として，より信頼性の高い溶射材料開発の
一環で，現用品の $\mathrm{HVOF}$ にる $\mathrm{Cr}_{3} \mathrm{C}_{2}-\mathrm{NiCr}$ 皮膜を主対 象に皮膜の基礎特性（組織，気孔率，硬さ，密着性，耐 摩耗性）試験やヒートサイクル試験, 高温エロージョン 試験，高温腐食試験等を実施した。各試験の結果をとり まとめると以下のとおりである.

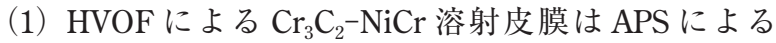
$\mathrm{Cr}_{3} \mathrm{C}_{2}-\mathrm{NiCr}$ 皮膜に比較して緻密で, 硬度が高く優れた密 着性を示したが, HVOF およびAPS ともに溶射距離が 長くなると皮膜中の酸化物等や空孔が増加し, 密着性も 低下することが確認された。特に HVOF は密着性の低 下が顕著であり，膜質管理上，実機溶射時の大きな課題 であることが確認された。

（2）実機条件を考慮したヒートサイクル試験の結果, 現用品は膜厚 $500 \mu \mathrm{m}$ 以上でクラック発生が確認され た。溶射皮膜のクラック発生は実用上極めて重要な問題 であり，ヒートサイクル試験の実施はこの種溶射皮膜の 特性評価に不可欠と考える.

（3）HVOF 溶射機（DJ1000）を使用して簡易的な高温 ブラストエロージョン試験を実施した。本試験方法と実 現象との相関性は今後検証する必要はあるものの, 試験 条件の改善，改良を実施すれば，高温での耐食・耐摩耗 溶射皮膜の相対的評価には有効と判断した.

（4）溶射皮膜の高温耐食性評価として実機腐食現象（硫 化腐食）を参考に, $\mathrm{H}_{2}-\mathrm{H}_{2} \mathrm{~S}$ による高温硫化腐食試験を 実施した。基材である STBA21S は顕著な高温硫化腐食 を発生したのに対し，現用品の $\mathrm{Cr}_{3} \mathrm{C}_{2}-\mathrm{NiCr}$ 溶射皮膜は 表層に僅かに腐食層が生成する程度で，その耐食性（耐 硫化腐食性）差を十分に評価できた。

以上，高温耐食・耐摩耗皮膜の開発に係る基礎デー夕 を得る為，現用品の $\mathrm{Cr}_{3} \mathrm{C}_{2}-\mathrm{NiCr}$ 溶射皮膜を主対象に各 種試験を実施し，新溶射材料開発の指針と評価方法に対 する検討項目を明らかにすることができた。

今後は今回得られた結果を基に，まず新規耐食・耐摩 耗候補材料の実験室的評価を行い，その後実機での実証 試験を経て実用化を図る予定であるが，溶射皮膜の経年 劣化把握も重要な課題であり，その評価方 法についても同時に検討する所存である.

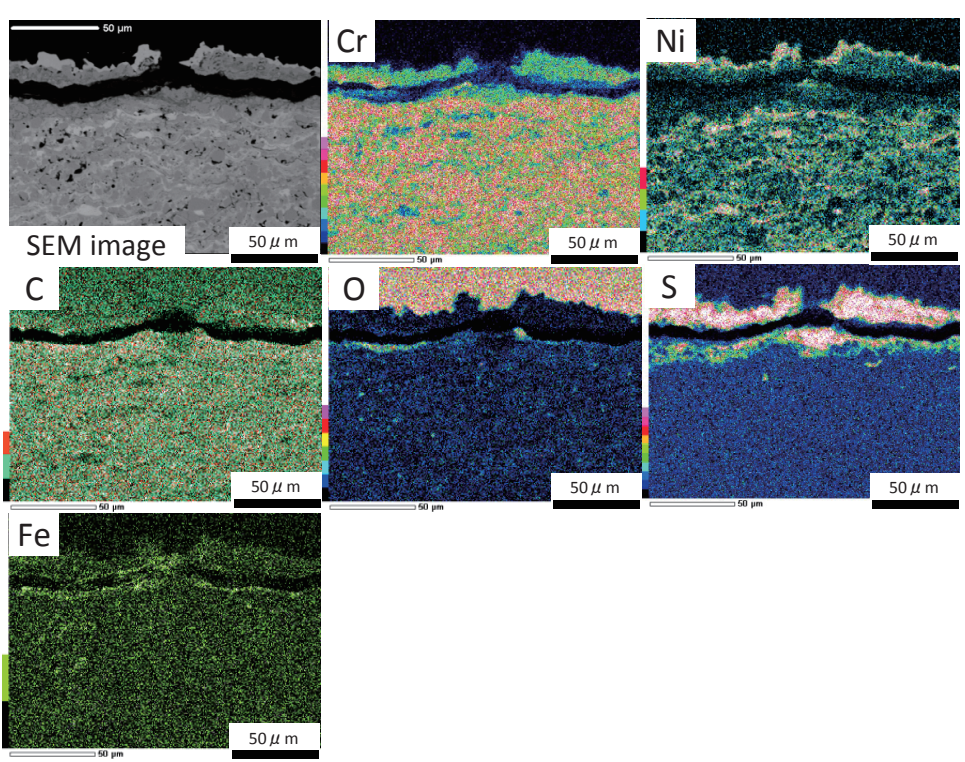

Fig.15 EDS elemental mapping of scale formed on HVOF coating prepared by DJ2700 after high temperature sulfidation test in $\mathrm{H}_{2}-\mathrm{H}_{2} \mathrm{~S}$.

\section{参 考 文 献}

1) S. Kyo, M. Nakamori, K. Kurokawa and T. Narita, Zairyo-to-Kankyo, 59, 456 (2010).

2) S. Kyo, M. Nakamori and K. Kurokawa, Zairyo-to-Kankyo, 60, 138 (2011).

3) M. Sasaki, F. Kawakami, C. Konami and M. Ishida, Proceedings of 13th International Thermal Spray Conference (ITSC'92), ASM International, p.165 (1992).

4) H. Fukumoto, H. Shimizu, N. Yamashita and Y. Shimizu, Proceedings of 14th International Thermal Spray Conference (ITSC'95), ASM International, 21 (1995).

5) C. J. Li, K. Sonoya, G. C. Ji and Y. Y Wang, Proceedings of 15th International Thermal Spray Conference (ITSC'98), ASM International, p.287 (1998).

6) D. J. Reardon, R. Mignogna and F. N. Longo, Thin Solid Films, 83, 345 (1981).

7) D. L. Houck and R. F. Cheney, Thin Solid Films, 118, 507 (1984)

8) P. Sahoo, Powder Metallurgy, 24, 73 (1993).

9) Y. Fukuda, Therm. Power, 56, 723 (2005).

10) T. Tomita, Y. Takatani, K. Tani and Y. Harada, 
Journal of High Temperature Society, 26, 248 (2000).

11）例えば, R. Uemichi, K. Yamamoto, I. Kajigaya, S. Nishimura, K. Tanaka and Y. Inui, Therm. Power, 55, 618 (2004).

12）例えば, T. Hayashida, T. Furue, M. Miyazaki, Y. Imaizumi, S. Tokura, N. Otsuka and N. Maruyama, Pro. of JSCE Materials and Environments 1996, p.419, JSCE (1996).

13) T. Tomita, Y. Takatani, K. Tani and Y. Harada, Journal of High Temperature Society, 26, 248 (2000).

14） K. Ueno, J. Jpn. Therm. Spray. Soc., 37, 183 (2000).

15) M. Nakamori, T. Aisaka, F. Yoshikawa, S. Takahashi and M. Yoshiba, Zairyo-to-Kankyo, 52, 650 (2003).

16) Y. Kawahara, K. Sasaki and Y. Nakagawa, Proc. 43th Japan. Conf. Materials and Environments, p.195, JSCE, (1996).
17) Japan society of thermal spraying, Thermal spraying technology handbook, p. 534 (1998).

18) Japan Thermal Spraying Society, Thermal sprayy technology an introduction, p. 216 (2012).

19) J. G. A. Bitter, Wear, 6, 5 (1963).

20) I. Finnie, Wear, 3, 87 (1960).

21) I. M. Hutchings, Wear, 70, 269 (1981).

22) S.Okazaki, K. Hasegawa, M. Takamori and M. Kiyoshige, Trans. Jpn. Soc. Mech. Eng., 56 [527] 1668 (1990).

(Manuscript received October 1, 2013; in final form December 10, 2013)

要旨

火力発電用ボイラにおいては, 長期安定運転が求められている.

近年, 微粉炭燃焼ボイラにおいて, 溝状腐食による伝熱管の減肉が顕在化している。溝状腐食は, バー ナーゾーンやその近傍, 熱負荷の高い部位に発生し, その発生原因は, $\mathrm{H}_{2}, \mathrm{H}_{2} \mathrm{~S}$ が混在する低 $\mathrm{O}_{2}$ 雲囲気 下で火炉側管表面に生じる繰り返し熱応力（スラグの付着脱落による局部的な管表面温度変化, デスラッ ガ作動中や運転中の管表面温度変化など）に起因する腐食生成物層のき裂発生等が原因であると考えられ る。その対応策として, ボイラ伝熱管表面への溶射は有効である。本報では, $\mathrm{Cr}_{3} \mathrm{C}_{2}-\mathrm{NiCr}$ 溶射皮膜を高速 フレーム溶射（HVOF）と大気プラズマ溶射（APS）によって作製した. 溶射皮膜の特性は，密着力，高 温硬さ，摺動摩耗試験，高温エロージョン試験および高温腐食試験などによって評価した．評価結果を基 に，実験室で石炭燃焼ボイラに適用するための溶射皮膜における評価方法を提案した.

キーワード＼cjkstart高温腐食, 石炭燃焼ボイラ, 蒸発管, ウォールブロワ, 溝状腐食, 硫化腐食, エロージ ヨン, 溶射皮膜, 大気プラズマ溶射，高速フレーム溶射 